ISSN : $2620-4665$ (print)

ISSN : $2620-4673$ (online)

Website : http://jurnal.untan.ac.id/index.php/JPLP2KM

\title{
PPUPIK PRODUKSI BENIH KEDELAI BERSERTIFIKAT DI POLITEKNIK PERTANIAN NEGERI KUPANG
}

\author{
Yosefina Lewar', Ali Hasan'1, Maria Klara Salli1 dan Haryati Sengaji1 \\ ${ }^{1}$ Politeknik Pertanian Negeri Kupang \\ email: yosefina.lewar087@gmail.com
}

\begin{abstract}
Soybean is an important commodity as a source of protein, raw material for various food industries and animal feed ingredients. Some of the factors that have led to an increase in domestic soybean demand are increased public awareness of nutrition and protein, increasingly high prices for animal-based side dishes, widespread use and export of soy sauce, and the shifting of the soybean processing industry from home industries to medium to large industries. This is also supported by one of the government programs since 2017-2021, namely the development of soybean plants nationally. The development of these commodities certainly requires the right quality seed, quantity, place, time, and price. With the rolling of the business program to increase production of each commodity, the potential need for quality seeds is quite large. The need for developing soybean seeds in ENT is quite high. Kupang State Politics as a vocational education institution in agriculture needs to develop a business unit for raising soybean seeds. This PPUPIK activity was carried out in 2018-2020 and after PPUPIK in 2021 it has the aim of making the State Agricultural Polytechnic of Kupang a center for certified soybean seed production that is commercial and available continuously.
\end{abstract}

Keywords: seeds, soybean, certified, PPUPIK, ENT

\section{PENDAHULUAN}

\subsection{Latar Belakang}

Benih bermutu merupakan salah satu faktor yang memegang peranan penting dalam budidaya. Ketersediaan benih bermutu tinggi menjadi salah satu kunci keberhasilan usaha di bidang pertanian. Ketersediaan benih dengan tepat mutu dan tepat waktu masih menjadi kendala di tingkat petani, sehingga berakibat pada penggunaan benih bermutu masih sangat terbatas. Benih bermutu tinggi mempunyai sifat fisiologis, fisik, kimia, dan genetik yang baik serta dipengaruhi oleh proses produksi (Copelland, 1976) termasuk tanaman kedelai. Data Badan Pusat Statistik Provinsi Nusa Tenggara Timur mencatat bahwa produksi produksi kedelai di NTT mengalami peningkatan yakni tahun 2015 hanya mencapai 2.615 ton, tahun 2016 meningkat menjadi 5.834 ton, dan tahun 2017 meningkat lagi menjadi 6.303 ton. Hal ini pengaruhi peningkatan luas areal penanaman sebagai dampak dari program PAJALE (Padi - Jagung - Kedelai) dari Kementerian Pertanian Republik Indonesia. Komoditas 
tersebut akan terus ditingkatkan produksi dan produktivitasnya, dengan salah satu faktor yang perlu diperhatikan adalah ketersediaan benih bersertifikat. Kebutuhan benih kedelai nasional untuk NTT mencapai 162,6 ton/tahun dan akan terus meningkat seiring dengan perluasan areal penanaman, namun terkendala penangkaran benihnya masih kurang sehingga setiap musim tanam benih kedelai masih juga diimpor dari luar NTT dan bahkan menggunakan benih dari hasil panen musim sebelumnya yang tidak diketahui secara pasti mutunya.

Berdasarkan permasalahan tersebut, maka Politani Negeri Kupang sebagai lembaga pendidikan vokasi bidang pertanian perlu mengembangkan unit usaha penangkaran benih melalui kegiatan Program Pengembangan Usaha Produk Intelektual Kampus (PPUPIK). Kompetitor dalam kaitan dengan unit usaha tersebut di masyarakat Nusa Tenggara Timur khususnya Kota dan Kabupaten Kupang masih sangat kecil. Hal ini karena produsen atau penangkar benih kedelai masih kurang sehingga peluang pengembangan usaha ini sangat besar. Unit usaha dalam kegiatan PPUPIK ini juga menjadi media belajar kewirausahaan bagi siswa SMK Pertanian, media penelitian bagi mahasiswa Politani Kupang, serta wadah belajar teknologi dari masyarakat NTT khususnya Kota dan Kabupaten Kupang.

\subsection{Dampak dan Manfaat}

Dampak dan manfaat dari kegiatan adalah 1) tersedianya unit sentra produksi benih kedelai bersertifikat di Politani Negeri Kupang, 2) kontinuitas ketersediaan benih, 3) laboratorium lapangan bagi kegiatan pelatihan, magang, dan penelitian, 4) sumber pendapatan institusi, 5) penyebarluasan ipteks hasil penelitian, 6) menumbuhkembangkan jiwa kewirausaan di bidang produksi benih dan membuka lapangan kerja baru, 7) membantu pemerintah dalam memenuhi kebutuhan benih bersertifikat di NTT secara khusus dan nasional umumnya karena apabila unit usaha semakin besar maka produksi benih yang dihasilkan dapat dipasarkan di luar NTT, dan 8) membantu meningkatkan produksi kedelai di tingkat petani karena menggunakan benih bersertifikat. 
ISSN : $2620-4665$ (print)

ISSN : $2620-4673$ (online)

Website : http://jurnal.untan.ac.id/index.php/JPLP2KM

\section{METODE PELAKSANAAN}

\subsection{Waktu dan Tempat Pelaksanaan}

Kegiatan dilaksanakan pada bulan April - September 2019. Kegiatan dilakukukan di kampus Politeknik Pertanian Negeri Kupang yaitu kebun kampus di Desa Baumata Kecamatan Taebenu Kabupaten Kupang.

\subsection{Waktu dan Tempat Pelaksanaan}

\section{Persiapan Bahan Baku dan Peralatan Penunjang}

Bahan baku pada usaha PPUPIK adalah 1) bahan baku utama yakni benih sumber dari kelas Sebar, dan 2) bahan baku penunjang seperti Furadan 3G, pupuk kandang, NPK, Urea, $\mathrm{KCl}$ KNO3 merah dan putih, biochar, pestisida kimia, pesnab tembelekan, plastik kemasan benih, stiker kemasan, label benih untuk proses produksi benih. Peralatan penunjang antara lain hand traktor, pacul, sekop, tandon air, tali rafia, meteran roll, mesin air, selang irigasi, gentong, parang, ember, sprayer, nyiru, terpal, gembor, timbangan elektrik, dan show case.

\section{Proses Produksi}

\section{Proses budidaya produksi benih}
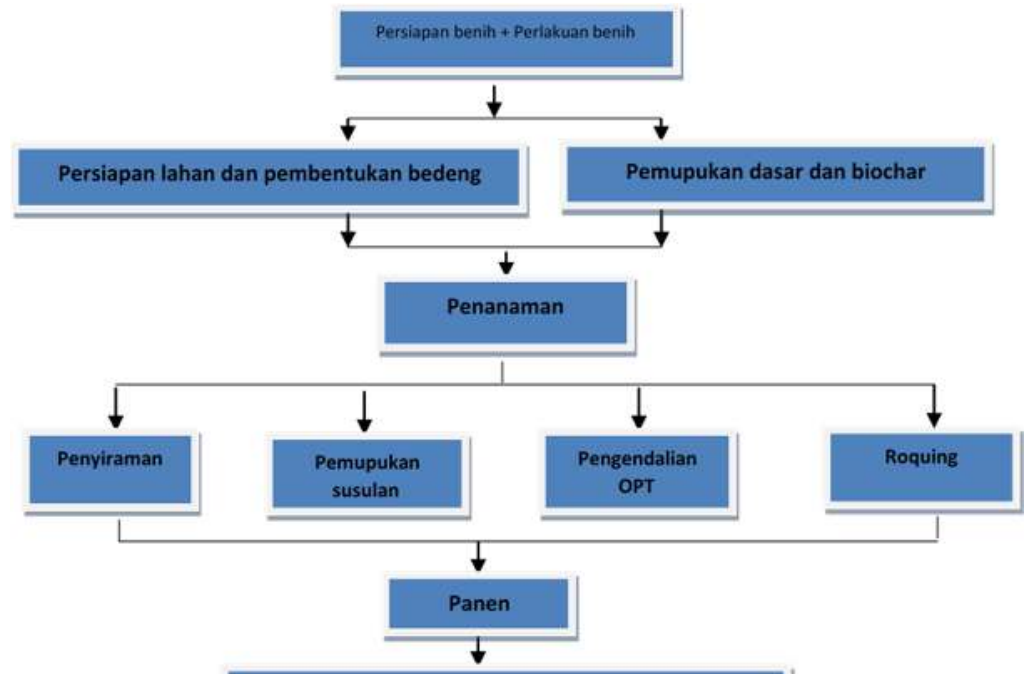

Penjemuran polong + Pembijian + Penjemur Benih

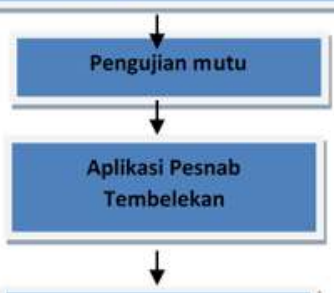

Pelabelan + Pengemasan 
I. LAHAN PRODUKSI BENIH BERSERTIFIKAT

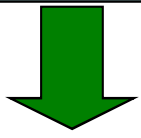

II. PEMERIKSAAN LAPANGAN

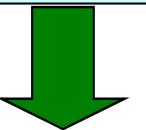

III. PANEN DAN PENGOLAHAN HASIL

Ambil Sampel Benih

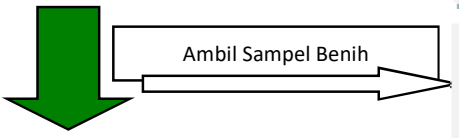

IV. PENGUJIAN LABORATORIUM

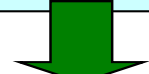

Vi. Pengawasan pemasangan LABEL (BENIH BERSERTIFIKAT)

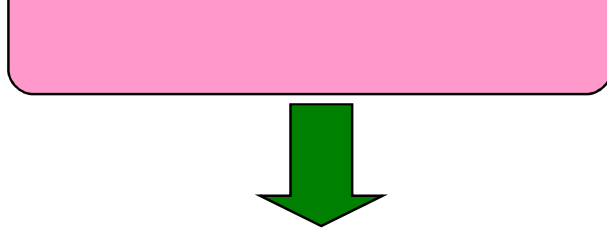

\section{LABEL \\ V. PERMOHONAN CETAK}

1. Mengajukan Permohonan ke UPTD PSB

2. Benih sumber harus jelas

3. Isolasi jarak harus jelas (BS, BD, BP, BR)

4. Luas, letak dan batas-batas lokasi harus jelas

5. Membayar biaya sertifikasi sesuai PERDA No 11.2001

1. Pendahuluan

2. Pemeriksaan pertama (vegetatif)

3. Pemeriksaan kedua (generatif)

4. Pemerikaan ketiga (masak)

1. Pemeriksaan Alat panen

2. Pemeriksaan Alat Pengolahan

3. Kebersihan Lantai Jemur dan Gudang)

1. Uji daya kecambah

2. Uji Kadar Air

3. Uji kemurnian

4. Uji Campuran Varietas Lain (CVL)

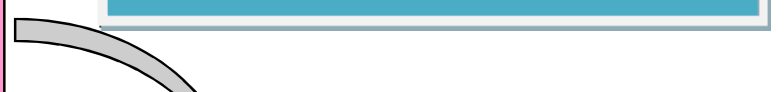

LULUS

\section{Pemasaran}

Pemasaran dapat dilakukan jika proses produksi telah memberikan hasil. Hal yang perlu diperhatikan dalam pemasaran produk PPUPIK adalah luasan pasar yang menerima produk dan teknik pemasaran. Pada dasarnya yang membeli produk utama adalah konsumen pengguna benih di tingkat Kota dan Kabupaten Kupang serta kabupaten lainnya di NTT, yakni a) konsumen tingkat pertama yaitu pedagang benih (kios dan toko pertanian), Pemda, 
ISSN : $2620-4665$ (print)

ISSN : $2620-4673$ (online)

Website : http://jurnal.untan.ac.id/index.php/JPLP2KM

kampus, dan LSM; dan b) petani. Sebelum dilakukan penjualan produk dilakukan promosi dan sosialisasi kepada calon konsumen. Promosi produk dilakukan melalui berbagai cara antara lain promosi langsung kepada konsumen, kontrak kerjasama, kegiatan wisuda Politani, kegiatan pameran expo Politani, kegiatan pameran pembangunan pemda, penyebaran brosur, dan iklan di media cetak maupun media sosial.

\section{HASIL DAN PEMBAHASAN}

\subsection{Proses Produksi}

\section{- Pendaftaran penangkaran}

Pendaftaran penangkaran benih dilakukan oleh tim pelaksana di UPTD PSB Provinsi NTT dengan mengisi formulir pendaftaran dengan melampirkan label benih sumber. Benih sumber kelas sebar berlabel biru, sehingga benih yang akan dihasilkan adalah benih kelas sebar 1.

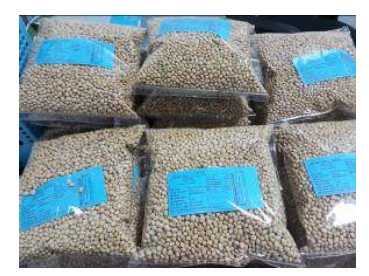

Gambar 1. Benih Sumber Kacang Merah

\section{- Pemeriksaan lapangan}

Pemeriksaan lapangan dilakukan oleh pengawas benih yang ditunjuk oleh UPTD PSB NTT untuk wilayah Kabupaten Kupang karena area produksi benih kedelai masuk dalam wilayah administratif Kabupaten Kupang yakni di Desa Baumata Kecamatan Taebenu.

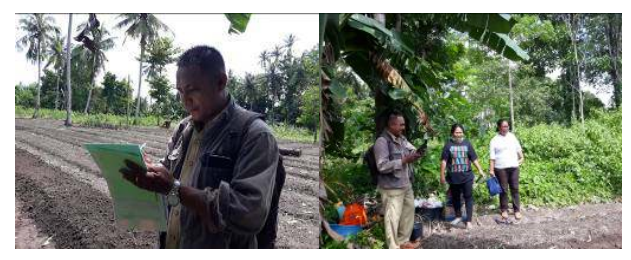

Gambar 2. Inspeksi Lapangan oleh Pengawas Benih 


\section{- Persiapan lahan}

Lahan untuk penanaman kacang adalah bekas lahan penanaman tanaman sayuran (sawi dan kangkung). Lahan yang digunakan dibersihkan dari sisa tanaman dan gulma rumput dan Chromolaena oddoratta yang tumbuh. Pembersihan lahan menggunakan sabit dan parang. Kegiatan pengolahan tanah seluas 1 ha menggunakan hand traktor dan cangkul. Setelah pengolaan tanah maka dilanjutkan dengan pembentukan bedeng atau petak penanaman. Bedeng dibuat ukuran panjang $10-15 \mathrm{~m}$ dan lebar $2 \mathrm{~m}$.

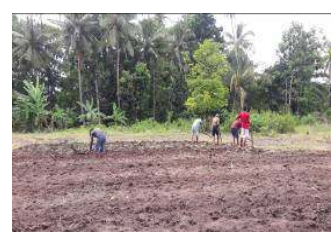

\section{- Pemupukan dasar}

Gambar 3. Persiapan Lahan

Setelah bedeng terbentuk maka dilanjutkan dengan pemberian pupuk dasar yakni pupuk kandang 15 ton yang dicampur dengan biochar sekam 8 ton/ha. Setelah pemberian pupuk organik maka bedengan diratakan lagi menggunakan cangkul sampai rata. Kemudian bedeng dibiarkan selama seminggu sebelum dilakukan penanaman benih kedelai.

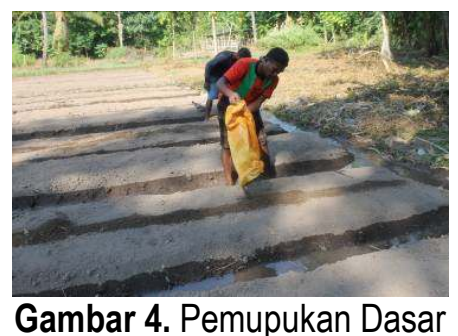

\section{- Penanaman}

Kegiatan penanaman dilakukan dengan terlebih dahulu berkoordinasi dengan pengawas benih agar diketahui dan dicatat tanggal penanamannya. Sebelum penanaman lahan diairi agar mempermudah penanaman dan mempercepat proses perkecambahan benih. Penanaman dilakukan dengan jarak tanam $40 \mathrm{~cm} \times 20 \mathrm{~cm}$ dengan jumlah benih 2 butir/lubang tanam. Benih yang ditanam berdasarkan data pada label benih tertulis persentase daya tumbuh $92 \%$. Untuk mencegah benih dimakan semut dan insekta tanah lainnya maka setelah penanaman ditaburi dengan Furadan 3G. Dalam kegiatan penanaman dilakukan oleh tim pelaksana, tenaga lapangan, alumni, dan mahasiswa. 


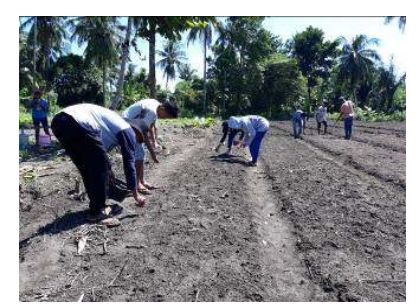

Gambar 5. Kegiatan Penanaman

\section{- Pemeliharaan tanaman}

Kegiatan pemeliharaan yang dilakukan antara lain pengairan, pemupukan, dan pengendalian organime pengganggu tanaman. Kegiatan penyiraman dilakukan sebanyak 2 kali seminggu. Penyiraman menggunakan air irigasi yang bersumber dari sumber air Baumata dengan cara mengalirkannya ke lokasi tanaman melalui saluran yang dibuat antar bedeng. Benih tumbuh pada umur 3 hari setelah tanam dengan persentase daya tumbuh $95 \%$. Sebanyak $5 \%$ benih tidak tumbuh atau abnormal sehingga dilakukan penyulaman menggunakan sisa benih pada saat penanaman.

Pemupukan susulan menggunakan pupuk anorganik dan organik. Pupuk anorganik yang digunakan adalah NPK $200 \mathrm{~kg}$, urea $200 \mathrm{~kg}, \mathrm{KCl} 50 \mathrm{~kg}$, KNO3 merah dan putih $25 \mathrm{~kg}$ yang diberikan saat tanaman berumur 2, 4, 6, 8 minggu setelah tanam. Pupuk organik yang diberikan adalah pupuk Superbiota plus pada saat tanaman berumur 3, 6, dan 9 minggu setelah tanam dengan dosis $30 \mathrm{ml}$ per 15 liter air.

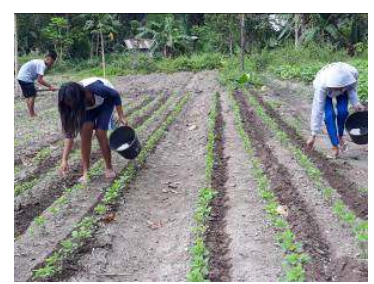

Gambar 6. Pemupukan Susulan

Pengendalian organisme tanaman yakni gulma dan hama yang menyerang tanaman kedelai. Gulma yang tumbuh tidak terlalu banyak sehingga pengendalian secara mekanik yakni menggunakan tajak atau tofa. Sedangkan hama yang menyerang tanaman adalah kepik hijau dan coklat yang menyerang tanaman pada saat tanaman berumur 2, 4, dan 6 minggu setelah tanam. Pengendalian menggunakan pestisida Alika, Decis, dan Demolish. 


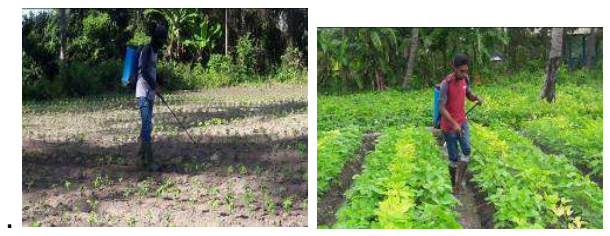

Gambar 7. Pengendalian OPT

\section{- Roquning dan Inspeksi Lapangan}

Roquing dilakukan sebelum dilakukan inspeksi atau pemeriksaan lapangan oleh pengawas benih dari UPTD PSB Provinsi NTT. Roquing dilakukan dengan mencabut tanaman yang bukan varietas yang ditanam serta mencabut gulma yang tumbuh dalam pertanaman produksi benih kedelai. Pemeriksaan dilakukan pada pertumbuhan tanaman fase vegetatif dan fase generatif.

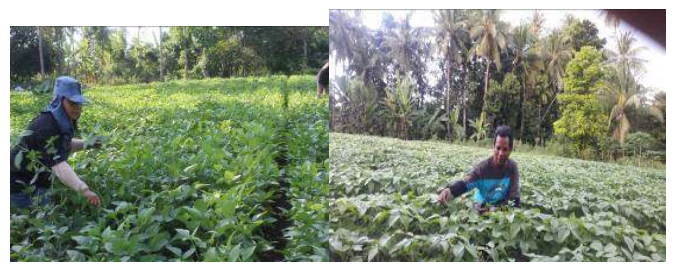

Gambar 8. Roquing

Lokasi pengembangan benih kedelai juga dikunjungi oleh petani dari desa sekitar sehingga mereka juga berkeinginan untuk menanam kedelai pasca pemanenan padi sawah. Menurut petani tersebut bahwa kegiatan produksi atau penangkaran benih di Desa Baumata hampir tidak ada, kebanyakan petani berusaha tani non benih.

\section{- Panen}

Tanaman produksi benih kedelai dipanen pada umur 65 hari setelah tanam. Panen dilakukan sekaligus. Panen dilakukan dengan cara memotong tanaman tepat di permukaan tanah dengan tujuan meninggalkan akar yang tertempel bintil akar untuk dimanfaatkan oleh tanaman berikutnya. Kemudian memetik polong yang menempel pada batang dan cabang tanaman.

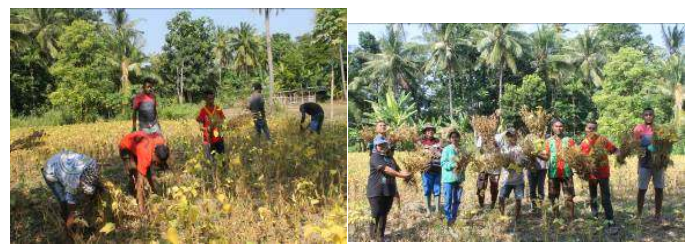

Gambar 9. Panen Kacang Merah 
ISSN : $2620-4665$ (print)

ISSN : 2620 - 4673 (online)

Website : http://jurnal.untan.ac.id/index.php/JPLP2KM

\section{- Pengolahan Benih}

Polong yang dipanen kemudian dijemur di bawah sinar matahari selama sehari, kemudian dilakukan pembijiian. Biji yang telah dihasilkan kemudian dijemur untuk menurunkan kadar air menjadi $10 \%$, setelah itu dilakukan sortasi untuk membuang benih yang ukurannya kecil dan abnormal. Stelah diperoleh benih dengan ukuran seragam kemudian dilakukan pengemasan benih untuk penyimpanan sementara sambil menunggu pengujian laboratorium.

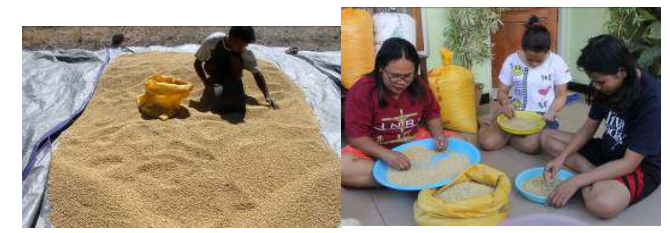

Gambar 10. Pengolahan Benih

\section{- Pengujian Mutu Benih}

Pengujian mutu benih dilakukan oleh analis benih dari UPTD Pengawasan dan Sertifikasi Benih NTT. Kegiatan diawali dengan pengambilan sampel benih oleh pengawas benih.

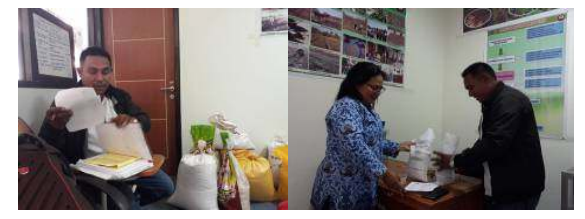

Gambar 11. Pengambilan Sampel Benih

\section{- Pengemasan dan Pelabelan}

Benih kedelai dikemas dalam plastik kemasan polietilen beraluminium foil. Benih dikemas dalam kemasan $4 \mathrm{~kg}$ dan $1 \mathrm{~kg}$. Plastik kemasan dipasang stiker dan kemudian benih dimasukan kedalam dan dipasang label benih. Benih yang dihasilkan dalam kelas Benih Sebar-1 (Br1).

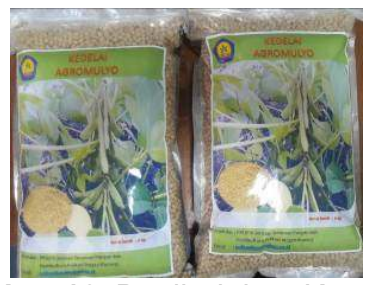

Gambar 12. Benih dalam Kemasan 


\section{HASIL DAN PEMASARAN}

Produksi benih kedelai yang diperoleh dari luasan $3.000 \mathrm{~m}^{2}$ adalah $300 \mathrm{~kg}$ benih. Penjualan benih kedelai sebanyak $300 \mathrm{~kg}$ dengan harga Rp. 50.000/kg sehingga diperoleh penerimaan sebesar Rp. 15.000.000. Benih dijual kepada konsumen yakni civitas akademika Politani Kupang, dan masyarakat umum. Penjualan dengan cara promosi di media sosial dan komunikasi lisan dengan para calon pembeli. Dalam kegiatan PPUPIK produksi benih kedelai ini melibatkan mahasiswa sebanyak 10 orang serta alumni sebanyak 3 orang.

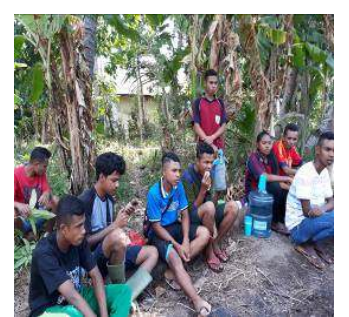

Gambar 13. Kegiatan Diskusi dengan Mahasiswa dan Siswa SMK

Berdasarkan hasil penilaian tim pelaksana menunjukan bahwa terjadi peningkatan pengetahuan dan keterampilan para mahasiswa, siswa dan alumni tentang teknologi produksi benih kedelai. Hal ini terlihat dari hasil pengujian secara lisan pra dan pasca kegiatan. Harapan dari tim pelaksana agar mereka dapat menerapkannya setelah kembali ke daerah masing-masing.

\subsection{PENERAPAN IPTEKS YANG DILAKUKAN}

Teknologi yang telah diterapkan dalam kegiatan produksi benih yakni penerapan teknologi budidaya berdasarkan hasil penelitian tim pelaksana yakni 1) penerapan teknologi budidaya produksi benih kedelai melalui 1) pemupukan yakni $\mathrm{NPK}, \mathrm{KNO}_{3}$ merah dan putih, $\mathrm{KCl}$, pupuk organik cair, 2) penggunaan biochar sekam padi dan kompos kotoran ayam petelur sebagai sumber hara dan pembenah tanah karena jenis tanah yang digunakan dalam kegiatan PPUPIK adalah tanah lempung berpasir, 3) aplikasi kinetin pada pertanman kedelai. Tanah lempung berpasir memiliki sifat kemantapan agregat tanah yang tidak stabil, tanah tersebut didominasi oleh partikel pasir, tetapi tidak cukup mengandung liat dan sedimen untuk menyediakan beberapa struktur dan kesuburan (Kusuma, C. A, 2017). Salah satu manfaat biochar pada lahan kering adalah meningkatkan kemampuan tanah merentensi air dan hara dibandingkan dengan bahan pembenah tanah yang lain, biochar mempunyai keunggulan antara lain a) dapat mengurangi laju emisi $\mathrm{CO}_{2}$, b) bentuknya yang 
ISSN : $2620-4665$ (print)

ISSN : $2620-4673$ (online)

Website : http://jurnal.untan.ac.id/index.php/JPLP2KM

stabil (sulit didekomposisi) dalam tanah, biochar mampu bertahan dalam tanah untuk waktu lama (> 400 tahun) dan berfungsi sebagai konservasi karbon, dan c) dapat membentuk habitat yang baik bagi mikroorganisme (Komarayati, dkk, 2003; Seso Kristoforus, dkk. 2015; Lewar, dkk. 2017). Penggunaan zat pengatur tumbuh pada tanaman kedelai sebagai salah satu upaya mengurangi cekaman kekeringan pada tanaman kedelai. Lewar, dkk (2007) menyatakan bahwa penyemprotan kinetin berpengaruh nyata terhadap pertumbuhan, hasil dan kualitas benih tanaman kacang hijau varietas Fore Belu yang mengalami cekaman kekeringan selama fase generatif. Sehingga penggunaan kinetin dalam kegiatan PPUPIK sebagai upaya mengatasi cekaman kekeringan pada tanaman kedelai yang diproduksi saat musim kemarau.

\subsection{KEUNIKAN PRODUK}

Produk yang dihasilkan dalam kegiatan PPUPIK ini memiliki keunikan dan keunggulan antara lain a) benih yang lebih bermutu karena melalui proses sertifikasi yang dilakukan oleh UPTD Pengawasan dan Sertifikasi Benih NTT, b) tingkat kemurnian benih yang dihasilkan lebih tinggi dan c) kualitas kimia benih terutama kadar protein benih yang tinggi sebagai cadangan makanan benih untuk perkecambahan karena mendapat input pemupukan NPK, $\mathrm{KNO3,} \mathrm{KCl}$ mencukupi, serta d) benih yang diproduksi lebih tahan disimpan karena dilindungi dengan pestisida nabati tembelekan/daun sirih sehingga terhindar dari serangan hama gudang (Mutha Kasi Takdir, dkk. 2016). Produk PPUPIK ini juga dikemas dalam kemasan yang baik dan desain stiker kemasan yang menarik serta tersedia secara kontinyu. Unit usaha PPUPIK ini dapat menjadi media belajar kewirausahaan bagi mahasiswa, alumni, dan siswa SMK Pertanian Lobalain NTT.

\section{PENUTUP}

Kegiatan PPUPIK Produksi Benih Kedelai telah berjalan dengan baik sesuai prosedur yang telah diatur dalam International Seed Testing Asociation (ISTA) sebagai jaminan mutu atas produk yang dihasilkan. Proses produksi yang telah dilakukan adalah pendaftaran penangkaran benih, inspeksi lapangan pendahuluan, persiapan lahan dan penanaman, pemeliharaan, roquing dan inspeksi lapang setiap fase pertumbuhan tanaman, panen, pengolahan benih, pengambilan sampel benih untuk pengujian laboratorium untuk penerbitan label benih serta pemasaran benih bersertifikat. 
Kegiatan ini melibatkan mahasiswa, alumni, dan siswa dari SMK Pertanian Lobalain Nusa Tenggara Timur yang melakukan praktek kerja industri. Kegiatan ini dapat menambah wawasan dan keterampilan mereka tentang produksi benih kedelai bersertifikat.

\section{DAFTAR PUSTAKA}

Badan Pusat Statistik Nusa Tenggara timur. 2017. ProduksiKedelai (ton) Menurut Kabupaten/ Kota di Provinsi Nusa Tenggara Timur, 2017. https://ntt.bps.go.id/dynamictable/2018/10/30/863/produksi-kedelai-ton-menurutkabupaten-kota-di-provinsi-nusa-tenggara-timur-2017.html.

Hasan Mochammad, Yosefina Lewar, dan Zainal Arifin, 2008. Produksi dan Kualitas Benih Kedelai Hitam Pada Jarak Tanam dan Kombinasi Dosis Pemupukan N, P, K Berbeda. Jurnal Partner Edisi Januari 2009. Politani Negeri Kupang.

Komarayati S. Pari dan Gusmailina, 2003. Pengembangan Penggunaan Arang untuk Rehabilitasi Lahan. Buletin Penelitian dan Pengembangan Kehutanan 4:1. Jakarta.

Kusuma, C. A. 2017. Perbaikan Sifat Fisik dan Kimia Tanah Lempung Berpasir. https://jtsl.ub.ac.id. Diakses 31 Agustus 2019.

Lewar Yosefina, Seni J. Bunga, dan Jemrifts Sonbai, 2007. Efektivitas Kinetin Terhadap Produksi dan Kualitas Benih Kacang Hijau Varietas Fore Belu Yang Mengalami Kekeringan Selama Fase Generatif. https://media.neliti.com/media/publications/158619-ID-efektivitas-kinetinterhadap-kualitas-be.pdf.

Lewar, Y., dan Mochammad Hasan. 2017b. Aplikasi Biochar dan Volume Pemberian Air Terhadap Produksi Benih Kacang Merah Varietas Inerie Ngada di Dataran Rendah Lahan Kering Beriklim Kering. Jurnal Penelitian Pertanian Terapan Volume 17 (3): 212-219. eISSN 2047-1781. jurnal.polinela.ac.id/index.php/JPPT/article/view/349.

Mutha Kasi Takdir, Yosefina Lewar, dan Nina J. Lapinangga, 2016. Aplikasi Tepung Pestisida Nabati Terhadap Mortalitas Kumbang Bubuk (Sitophilus zeamays) dan Viabilitas Benih Kacang Merah Varietas Inerie dalam Penyimpanan. Laporan Penelitian. Politeknik Pertanian Negeri Kupang.

Seso Christoforus dan Yosefina Lewar. 2015. Pertumbuhan dan Hasil Bawang Merah Varietas Bima Akibat Pemberian Dosis Biochar Campuran Kompos Kotoran Sapi dan Arang Sekam. Laporan Penelitian Terapan. Politani Negeri Kupang. 